\title{
USE OF FORMOTEROL IN THE TREATMENT OF STUTTERING. A PILOT STUDY
}

\author{
Josef Pesak ${ }^{\mathrm{a}}$, Jana Zapletalova ${ }^{\mathrm{a}}$, Tomas Grezla, b \\ ${ }^{a}$ Department of Biophysics, Faculty of Medicine and Dentistry, Palacky University Olomouc, Czech Republic \\ ${ }^{b}$ ORL Department, District Hospital in Kromeriz, Czech Republic
}

Received: April 6, 2009; Accepted: September 1, 2009

Key words: Stuttering/Bronchodilatation/Formoterol (Foradil $($ )

Aims: Stuttering is a serious health and social problem that can distinctively affect not only the mental development of an individual but also his life possibilities, including social fulfilment and his general life prospects. The etiology of stuttering is however unknown and that is why it is not possible to treat it causally. This pilot study takes into account the hypothesis of bronchial constriction as a negative factor in stuttering and investigates the effect of the long-acting bronchodilator formoterol fumarate on stuttering in 42 patients.

Methods: Patients were divided in 2 groups - A (school children and juveniles) and B (adults 18-25 resistant to other treatment). The medicine was administered once a day in the morning in a dose of $12 \mu \mathrm{g}$ for the total period of 6 months. The prime outcome parameter - severity of stuttering - was evaluated using the ordinary scale (McGill Pain Questionnaire). The evaluation was done by an examining physician during visits to the centres and by the patients themselves (in cases of the youngest with the assistance of a parent) in a daily diary.

Results: A non-parametric pair test (Wilcoxon signed rank test) was used to compare the average marks in the whole set of patients. During the six moth period of administration of Foradil ${ }^{\circledR}$ the speech fluency improved. The average number of dysfluent words decreased from $10.5 \pm 1.3$ to $6.6 \pm 0.97$.

Conclusion: The average mark of speech fluency evaluated by the physicians between the period of non use of Foradil $^{\circledR}$ and the six month period after the use of Foradil ${ }^{\circledR}$ improved from $2.95 \pm 0.76$ to $1.95 \pm 0.56$ (as proved by the chi-square test, $\mathrm{p}<0.0001$ ). The evaluation of speech fluency of balbuties uses the logopedic practices. Other clinical evaluations of speech fluency are not known.

Stuttering is "explicitly" a disease ${ }^{1}$. It causes serious health and social problems that can distinctively affect not only the mental development of an individual but also their life possibilities, including social fulfilment and general life prospects. From the fact that in a small percentage of afflicted children stuttering improves spontaneously in adulthood, a false impression arises that stuttering does not deserve such great attention. Even though stuttering can improve spontaneously, it is necessary to note that it does not happen without reasons.

In cases of severely stuttering people frustration can displace them from their life positions; a case is even recorded of a thirteen-year-old boy who stuttered and decided to end his life voluntarily².

Stuttering has been known for about four millenniums $^{3}$. Richard Kitchen and Van Riper collected more than 70 nouns of stutterers all over the world. Thus, stuttering is a communication disorder occurring independently of locality, population type, etc. The following information came from the history of Czech Phoniatry. In 1934 Seeman formulated a hypothesis that the symptoms of stuttering do not emerge directly from striopallidal pathological-anatomical changes but rather from striopallidal dynamic deviations after strong affects ${ }^{1}$. He also thought that these states were not permanent and they could not be sustained by themselves but they are caused again and again by repeated conflict situations. Due to the fear of stuttering the activity of striopallida is arrested which results in a rise of hypertonia and hyperkinesis in the musculature of the vocal organ. In the end only a light stutter in speech or only an image of disability to pronounce a certain sound is enough to arise such intense excitement that it provokes another attack of stuttering" 1 . In the end, Laštovka states that: „From all opinions and theories about the origin of stuttering we can conclude that all these theories agree in fact that stuttering is a central disorder of motor control in which emotions play a dominant role. The etiology of stuttering is however unknown ${ }^{4}$ and that is why it is not possible to treat it causally in spite of research ${ }^{5-6}$.

Seeman ${ }^{7}$ urges ,that most physicians should not behave completely unconcernedly towards the treatment of stuttering and that the treatment of this disease should not be only in the hands of specialists without any medical education. His wish has, however, so far spread neither to medical nor to educational sphere.

Despite the fact that Seeman admitted the possibility of finding frequent deviations of respiratory motions in stutterers pneumographically, he assumed that their breathing at rest was completely unbroken ${ }^{1-7}$. However, current studies have offered new pieces of knowledge that have emerged from functional pulmonary investigation in stuttering children and young people ${ }^{8-9}$. Functional pulmonary examinations were made in 60 children and young 
people and their static pulmonary volumes, and their mutual relations and ventilation values were compared with the results of the examinations of a group of healthy children and juveniles ${ }^{10}$. The studies found volume reduction of all pulmonary capacities, reduction of the relation of inspiratory capacity to expiratory reserve volume and, in contrast, an increase of the relation of residual volume to total pulmonary capacity and increase in relation of functional residual capacity to total pulmonary capacity. One-minute ventilation values were found considerably spread and totally reduced; perturbations were found as increased flow resistance and proportionately decreased specific conductivity.

Probably the most suspicious functional parameter of the lungs is decreased specific conductivity $1.08 \pm$ $0.481 / \mathrm{s} / \mathrm{kPa}(\mathrm{p}<0.0001)$ compared to the normative values of $1.97 \pm 0.45 \mathrm{l} / \mathrm{s} / \mathrm{kPa}$ for the healthy population ${ }^{8}$. Obviously the same cause, i.e. decreased specific conductivity in stuttering children and juveniles, results in the shift of respiratory position at rest into inspiratory position of the chest as it compares to respiratory volume in healthy population. The described pulmonary pathology may be considered the suspect cause of stuttering ${ }^{11}$. The presented study attempts to pharmacologically increase the specific conductivity of stutterers using the bronchodilator formoterol fumarate and investigates its effect on stuttering in 42 patients.

\section{MATERIAL AND METHODS}

A pilot study was carried out in six centers in the Czech Republic in accordance with a united protocol (set in compliance with Helsinki Declaration of the World Medical Association and approved by the Ethics Committee) for the period of 6 months. 42 patients with the diagnosis of stuttering (F98.5) were involved. Patients were divided into two groups - A (school children and juvenils) and B (adults 18-25 resistant to other treatment), see Table 1.

The long-acting bronchodilator formoterol fumarate (acting via $\beta$, receptors) was applied once a day in the morning (by 10 a.m.) in a dose of $12 \mu \mathrm{g}$ (one inhalation capsule). This dose was the lowest possible effective dose according to Novartis. During the 6 months, the evaluation of effectiveness was performed in every patient on the basis of primary and secondary parameters. The prime parameter „severity of stuttering” was evaluated according to the ordinary scale $\mathrm{K}: 1$ = excellent, 2 = tolerable, 3 = bad,
$4=$ very bad, 5 = terrible - McGill Pain Questionnarie ${ }^{12}$. The severity of stuttering was evaluated by an examining physician during visits to the centres and also daily by the patients in their diaries (in cases of the youngest with the assistance of a parent). The patients self-evaluated their speech fluency daily for the whole duration of the study, i.e. 6-months. The physicians performed the perceptual evaluation four times throughout the study: at the beginning and then in two-month intervals. During these four visits, tape recordings of the patients' speech were done for objective analysis of the speech fluency. The patients were first provided with a text to read and were given 5-15 minutes to become familiar with it. Then the reading of this familiar text was recorded. After that, reading of an unfamiliar text was recorded. The texts were different for the group A (school children and juveniles) and B (adults) to respect the age difference. The tape recordings were retrospectively analyzed for stuttering severity by calculating the number of dysfluent words per 100 spoken words. Statistical analyses were performed using the SPSS, v.14 software package (SPSS Inc., Chicago, USA).

Several additional measurements were done by the physicians: initial EEG and EMG examinations were conducted; biochemical tests were performed at the beginning and at the end of the testing period, and spirometric values (measured with the help of impulsed oscillometry) and data on heart frequency variability were recorded during each visit. These data will be reported in further studies.

\section{RESULTS}

According to the records in a patient 's diary (i.e. evaluation of speech fluency by a mark from 1 to 5 , which was done by a patient himself/herself) there were 3 average value calculated in every patient: 1) an average value that evaluated the speech fluency in the period without formoterol, 2) an average value that evaluated the speech fluency in the first period of formoterol use, that is from the 1 st to the 3 rd month, and 3) an average value that evaluated the speech fluency in the second period of formoterol use, that is from the 4 th to the 6 th month. The results are shown in Table 2.

Non-parametric in dual test (Wilcoxon Signed Ranks test) was used for the comparison of average marks in the whole group of patients $(n=42)$ at a significance level of 0.05 .

Table 1. Information of the two groups used in the study: group A (school children and juveniles) and group B (adults 18-25 resistant to other treatment).

\begin{tabular}{|l|c|c|c|c|}
\hline Group & \multicolumn{2}{|c|}{ A } & \multicolumn{2}{c|}{ B } \\
\hline Gender & Men & Women & Men & 4 \\
\hline Number & 29 & 5 & 4 & 18.00 \\
\hline $\bar{x}$ [age] & 12.41 & 12.60 & 23.50 & 0.00 \\
\hline$s$ [age] & 2.80 & 2.19 & 2.52 & \\
\hline
\end{tabular}


Table 2. Patients' self-evaluation of their severity of stuttering.

\begin{tabular}{|l|c|c|c|}
\hline & $\begin{array}{l}\text { Average value prior to the } \\
\text { treatment (two weeks) } \\
\text { Period I }\end{array}$ & $\begin{array}{l}\text { Average value in the first half of } \\
\text { the treatment (month 1-3) } \\
\text { Period II }\end{array}$ & $\begin{array}{l}\text { Average value in the second } \\
\text { half of the treatment (month } \\
\text { 4-6) Period III }\end{array}$ \\
\hline $\mathrm{N}$ & 42 & 42 & 42 \\
\hline Minimum & 2.00 & 1.46 & 1.08 \\
\hline Maximum & 5.00 & 3.66 & 3.82 \\
\hline Median & 2.92 & 2.38 & 2.28 \\
\hline Mean & 2.94 & 2.49 & 2.32 \\
\hline SD & .633 & .472 & .579 \\
\hline
\end{tabular}

Table 3. Distribution of mark frequency on scale K evaluated by the physicians.

\begin{tabular}{|c|c|c|c|c|c|c|c|}
\hline & \multicolumn{5}{|c|}{ Scale K } & \multirow[b]{2}{*}{ Total } \\
\hline & & Excellent & $\begin{array}{l}\text { Tolerable } \\
\text { "not bad" }\end{array}$ & $\mathrm{Bad}$ & Very bad & Terrible & \\
\hline \multirow[t]{2}{*}{ Visit 1} & Count & 1 & 10 & 21 & 10 & 0 & 42 \\
\hline & $\%$ & 2.4 & 23.8 & 50.0 & 43.8 & 0 & 100 \\
\hline \multirow[t]{2}{*}{ Visit 2} & Count & 2 & 28 & 9 & 3 & 0 & 42 \\
\hline & $\%$ & 4.8 & 86.7 & 21.4 & 7.1 & 0 & 100 \\
\hline \multirow[t]{2}{*}{ Visit 3} & Count & 7 & 24 & 7 & 3 & 1 & 42 \\
\hline & $\%$ & 16.7 & 57.1 & 16.7 & 7.1 & 2.4 & 100 \\
\hline \multirow[t]{2}{*}{ Visit 4} & Count & 7 & 29 & 6 & 0 & 0 & 42 \\
\hline & $\%$ & 16.7 & 69.0 & 14.3 & 0 & 0 & 100 \\
\hline \multirow[t]{2}{*}{ Total } & Count & 17 & 91 & 43 & 16 & 1 & 168 \\
\hline & $\%$ & 10.1 & 54.2 & 25.6 & 9.5 & 0.6 & 100 \\
\hline
\end{tabular}

The patient's diary - an average mark

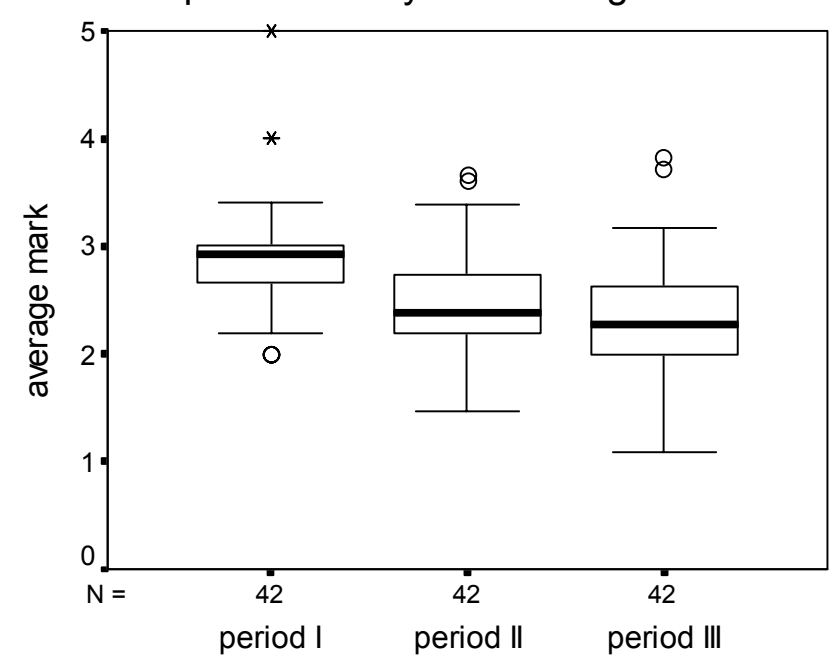

Fig. 1. Results of self-evaluation of patients on their severity of stuttering. The position of the median value is shown as a thick horizontal line for each period. The bottom and the top of the box identify the positions of the 1 st and 3 rd quartiles. The height of the box corresponds with the interquartile range, as the characteristics of the data variability. The bars mark the minimal and maximal non-distant values, the distant values (outliers, determined automatically by the SPSS package) are displayed as arteriscs or circles.
The test showed significant differences between the average values in the period I and II. The speech fluency evaluation was assessed as lower in period II, i.e. by a better count than in the period I (as proved by the chi-square test, $p<0.01$ ). Also a significant difference was found between average values in periods I and III. (as proved by the chi-square test, $p<0.01$ ) The speech fluency evaluation in period III is assessed as lower, i.e. by a better value than in period I. (as proved by the chi-square test, $\mathrm{p}<0.01$ ) Period II differs significantly from from period III. The speech fluency was evaluated by a better level in period III (see Fig. 1).

Distribution of mark frequency on scale K (evaluations by physicians) is presented in Table 3 . The results shows gradual improvement in speech fluency, i.e. increasing percentage of patients assessed as "excellent" or "not bad" during individual visits. Chi-square test confirmed significantly higher proportion of patients assessed as excellent" or "not bad" when comparing the visit 1 (prior to the treatment with formoterol) and 2, 1 and 3 and 1 and 4 , respectively.

To compare the speech fluency of individual patients during two visits (i.e. paired data comparison), two-dimensional frequency tables were made use of. The comparison of the first and the second evaluation showed an improvement in speech fluency in $27(64.2 \%)$ patients, unchanged speech in $9(21.4 \%)$ patients and worsened speech fluency in $6(14.4 \%)$ patients. The comparison of the first and the third evaluation showed an improvement 
Table 4. Severity of stuttering when reading the familiar text expressed by the number of dysfluent words per 100 words.

\begin{tabular}{|l|c|c|c|c|c|c|c|}
\hline \multicolumn{1}{|c|}{ Period } & N & Minimum & Maximum & Median & Mean & $\begin{array}{c}\text { Std. } \\
\text { Deviation }\end{array}$ & $\begin{array}{c}\text { Std. Error } \\
\text { of Mean }\end{array}$ \\
\hline Before Treatment & 42 & 0 & 30.7 & 6.9 & 10.1 & 9.1 & 1.4 \\
\hline After 2 months & 42 & 0 & 30.1 & 5.3 & 7.9 & 7.8 & 1.2 \\
\hline After 4 months & 42 & 0 & 31.5 & 4.4 & 7.4 & 7.6 & 1.2 \\
\hline After 6 months & 42 & 0 & 22.9 & 4.6 & 6.1 & 5.9 & .9 \\
\hline
\end{tabular}

Table 5. Severity of stuttering when reading the unfamiliar text expressed by the number of dysfluent words per 100 words.

\begin{tabular}{|l|c|c|c|c|c|c|c|}
\hline \multicolumn{1}{|c|}{ Period } & N & Minimum & Maximum & Median & Mean & $\begin{array}{c}\text { Std. } \\
\text { Deviation }\end{array}$ & $\begin{array}{c}\text { Std. Error } \\
\text { of Mean }\end{array}$ \\
\hline $\begin{array}{l}\text { Before } \\
\text { Treatment }\end{array}$ & 42 & 7 & 36.6 & 8.1 & 10.8 & 9.4 & 1.5 \\
\hline After 2 months & 42 & 0 & 23.9 & 5.1 & 6.7 & 6.3 & 1.0 \\
\hline After 4 months & 42 & 0 & 38.2 & 4.9 & 7.8 & 8.4 & 1.3 \\
\hline After 6 months & 42 & 0 & 26.6 & 5.2 & 7.0 & 6.8 & 1.1 \\
\hline
\end{tabular}

in speech fluency in $28(66.8 \%)$ patients, unchanged speech in $9(21.4 \%)$ patients and worsened speech fluency in $5(12.0 \%)$ patients. The comparison of the first and the fourth (final) evaluation showed an improvement in speech fluency in 33 (78.6\%) patients, unchanged speech in $7(16.7 \%)$ patients and worsened speech fluency in $2(4.8 \%)$ patients only.

Results of the measures of the severity of stuttering from the tape recodings are presented in Tables 4 and 5. The tables show decrease of the number of dysfluent words after the Foradil treatment started. The decrease was observed in both the familiar (Table 4) as well as unfamiliar texts (Table 5). For the familiar test, the Wilcoxon signed rank test revealed large significance values of 0.017 , 0.013 and 0.002 for the $2^{\text {nd }}, 4^{\text {th }}$ and $6^{\text {th }}$ month results when compared to the state before the treatment. At these intervals 28 out of 42 patients showed decreased number of dysfluent words after 2, 4 and 6 months of treatment, while 12, 11 and 11 patients showed increased number of dysfluent words after 2, 4 and 6 months, respectively.

For the unfamiliar test, the significance levels resulting from the Wilcoxon signed rank test were even larger than for the familiar text: $<0.0001,0.0005$ and 0.001 for the results after 2, 4 and 6 months when compared to the state before the treatment. At these intervals 34, 32 and 31 out of 42 patients respectively showed decreased number of dysfluent words after 2, 4 and 6 months of treatment, while 8,10 and 11 patients, respectively, showed increased severity expressed by increased number of dysfluent words.

The values averaged over both the familiar and unfamiliar tests are presented in Fig. 2. The Wilcoxon signed rank test again revealed statistically significant decrease in the severity of stuttering ( $p=0.0001,0.001$ and 0.001$)$ after 2, 4 and 6 months when compared to the state before treatment.

\section{DISCUSSION AND CONCLUSION}

The obtained data by bronchodilation of the tracheobronchial tree using formoterol support the hypothesis that the cause of balbuties is the pneumoobstruction of the tracheobronchial tree. The use of formoterol for bronchodilation of the tracheobronchial tree is original. Finding the original by searching the registered patent number 298331 of "the use of formoterol to prepare medicine for treating stuttering" 13 at the Pattent Office in Prague 6, Bubenec confirmed that till 2007 no one in the world or in the Czech Republic worked with formeterol in relation to stuttering. There are no other treaments, including pharmacological methods for treating stuttering mentioned $^{14}$.

The study aimed at testing the hypothesis of bronchial obstruction as a negative factor in stuttering. The longacting bronchodilator formoterol fumarate was applied in 42 patients and its effect on stuttering was evaluated. Decreased severity of stuttering was found in the self-evaluation of patients when using the formoterol. Statistically significant differences in the average marks of self-evalu-

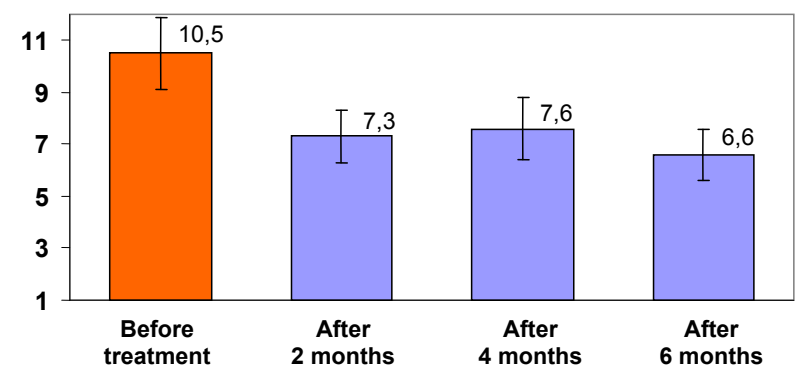

Fig. 2. The number of dysfluent words per 100 words, averaged over the familiar and unfamiliar texts. The error bars correspond to the standard error of mean. 
ation were found using the Wilcoxon Signed Ranks test. Evaluation of the speech by physicians (registered four times throughout the study - at the beginning and then in two-month intervals) confirmed the positive effect of pharmacological treatment on stuttering. ${ }^{15-16}$ For confirmation of the medication effect, a randomized placebocontrolled study is still needed. Such a control group was, unfortunately, not possible in this study for ethical and financial reasons.

\section{ACKNOWLEDGEMENT}

The research was done in accordance with the pilot study BZ-10003-BR "Verification of bronchodilation influence on speech fluency in stuttering children, juveniles and adults" which was partly supported by the research plan "MSM 152100018“.

\section{REFERENCES}

1. Laštovka M. Poruchy plynulosti řeči. [Speech Fluency Disorders] (In Czech). Scriptorium, spolek pro nekomerční vydávání odborné literatury. ISBN 80-86197-13-1, Praha 1999.

2. Švédová P. Školáci řeší problémy sebevraždami. [Pupils deal with problems by suicide]. (In Czech). Olomoucký den, Příloha víkend, č. 131, 2004.

3. Guitar B. Stuttering. An Integrated Approach to Its Nature and Treatment. $2^{\text {nd }}$ edition, Wiliams \& Wilkins, Baltimore, 1998.

4. Adams RD, Victor M. Principles of Neurology. McGraw-Hill Information Services Company, Fourth Edition, New York, 1989.

5. Bloodstein, O. Stuttering: The Search for a Cause and Cure. Allyn \& Bacon, Boston 1993.

6. Bloodstein O. A Handbook on Stuttering. Fifth Edition. Singular Publishing Group, Inc., San Diego - London 1995.
7. Seeman M. Poruchy dětské řeči. [Speech Disorders in Children]. (In Czech). Státní zdravotnické nakladatelství, Praha 1955.

8. Pešák J. Funkční vyšetření plic u dětí a mladistvých s balbuties. [Examining the Function of Lungs in Children and Juveniles with Balbuties]. (In Czech). Čs. Pediatrie, 43, č. 7.

9. Zapletal A, Šamánek M, Paul T. Funkce dýchacího ústrojí u dětí a mladistvých. [Function of Breathing Apparatus in Children and in Juvenils]. (In Czech). Osveta, Martin 1984.

10. Pešák J. Hypotéza pneumoobstrukční etiologie koktavosti. [Hypothesis of Pneumoobstruction Etiology of Stuttering]. (In Czech). In: Sborník přednášek 9. Semináře univerzitního Společenství pro studium hlasu a řeči, Ed: Dr. Josef Pešák, Ústav lékařské biofyziky LF UP v Olomouci, květen 2002.

11. Pešák J. Pneumoobstruction of the Tracheobronchial Tree as a Hypothetical Cause of Balbuties. Medical Hypotheses, 59 (4), 458461, 2002.

12. Malzack R. The short-form McGill Questionnaire. Pain 1987 Aug; 30 (2): 191-197.

13. Pattent No: CT/CZ2005/000026 Použití přípravku na bázi beta 2 sympatomimetika $\mathrm{k}$ omezení koktavosti [The Use of Medicine Based on $B_{2}$ Sympatomimetik to Decrease Stuttering]. (In Czech).

14. Fibiger $\mathrm{S}$, et al. Health and human services for persons who stutter and education of logopedics in East-European countries. Journal of Fluency Disorders 33(2008)66-71 23.

15. Pešák J. Preliminary experience with formoterol for treatment of stuttering. Letters and comments. Annals of Pharmacotherapy, Jul-Aug 2004, vol. 38, no 7-8, p. 13

16. Pešák J. Zmírňování zadrhávání v řeči u dětí a mladistvých s balbuties po aplikaci $\beta_{2}$ sympatomimetika formoterol. [Decreasing stuttering in children and in juvenils after the aplication of $\beta_{2}$ sympatomimetik formoterol]. (In Czech). Klin Farmakol Farm, 2004, roč. 18., s. 11-12

17. Honová J, Pešák J. Ověrování vlivu bronchodilatace na plynulost řeči u nezletilých i dospělých s balbuties, Součást výzkumného záměru „MSM 152100018“. [Diagnosis the influence of bronchodilatation in speech fluency in juvenils and in adults with balbuties, Part of a research task. (In Czech). Protokol: BZ-1003-BR, Finální verze 03. 11. 03, ZAK-Pharma Services s.r.o., Brno, 2003. 
